\title{
Development of physics comic based on local wisdom: Hopscotch (engklek) game android-assisted to improve mathematical representation ability and creative thinking of high school students
}

\author{
F. Permata Sari, S. Nikmah and H. Kuswanto \\ Physics Education, Graduate Program, \\ Universitas Negeri Yogyakarta, Yogyakarta, Indonesia \\ R. Wardani \\ Electrinic Engineering and Informatic Education, \\ Graduate Program, Universitas Negeri Yogyakarta, Yogyakarta, Indonesia
}

Received 5 April 2020; accepted 18 May 2020

Comics can be an effective educational tool at various levels of Education. Developmental trends of technology can be used as a learning medium. In this research, the comics are designed for operated using an android. This study aims to produce a local wisdom based physics comic media: hopscotch game that is suitable for learning impulse and momentum material in high school, and to know the effectiveness of the media used to improve mathematical representation and creative thinking of students. This research is a Research and Development (R\&D) using the Borg and Gall model. Research instruments include product assessment sheets, questionnaires, mathematical representation, and creative thinking tests. The data analysis technique used is the MANOVA test. The results show that the product is a media that is operated using a smartphone/ android with the EPUB-Reader application or a computer with an internet browser. The comic media contains impulse and momentum material, videos, examples, and practice questions. The product is categorized as suitable to be used in the physics learning process. There is a difference between the experimental and control classes. This shows that the local wisdom based Physics comic: android-assisted can improve mathematical representation and creative thinking of high school students.

Keywords: Physics comic; android; local wisdom; hopscotch; creativity; mathematical representation.

DOI: https://doi.org/10.31349/RevMexFisE.17.255

\section{Introduction}

Animation, comics, and games have a large output value and influence in the entertainment media market by in accordance with the development of life in recent years [1]. Comics are not only used as an entertainment tool, but can be used in education [2]. Conversational language in comics can change rigid science into simple science that can be accessed and understood by students [3]. At present, technology and information development trends can be used as a medium of learning, inside and outside the classroom [4].

Students can experiment and make a comic strip with their creativity. This fact reveals that investigations led by students can encourage the development of creativity and critical thinking [5]. The comic produced suggests the idea that educators can encourage students to learn if the curriculum and pedagogy are personally relevant and inspire creative and original ideas [6].

Comics can be an effective educational tool at various levels of education. Students who read comics can show an increased level of interest. The comic is expected to motivate other educators to produce different comics towards more flexible and embedded methods in organizing learning $[7,8]$. The development of scientific comics is needed to increase the involvement of more diverse students because physics textbooks only benefit high-achieving students [9]. Readers are more interested in learning physics through comics than learning through textbooks [3].
Experts give examples of integration in physics, chemistry, or biology, referring to all mathematics and learning units [10]. Physics learning can balance between scientific attitudes in physical knowledge and the value of local wisdom to build the nation's character $[11,12]$.

Multiple representations in problem-solving include verbal, diagram or picture, mathematics or symbolic, and graphic. The performance on math problems is worse than other formats despite students' preferences for calculation questions [13]. The discovery of mathematical representation can predict students' mathematical achievement [14].

The values of local wisdom should be explored again so that it may still exist following the changing of time and remain a characteristic of every region in Indonesia [15]. Local culture used in learning physics can change the rigid view of physics into "science for the future", "science for daily living", and "science for all" [16-18]. The traditional game of hopscotch contains the values of problem solving consisting of finding and understanding problems, developing good problem-solving strategies, and exploring solutions [19].

Teachers need to provide learning activities to encourage a more specific creativity or creative thinking of students. Imagination and creativity are considered important in science, so a good science education must be able to help foster students' imaginative abilities and creativity [20].

Reference [21] reveals that learning is an activity to acquire knowledge, skills, shape behavior and attitudes, and strengthen personality. Learning will be successful if stu- 
dents can understand the concept of the material [22]. The framework of technology, pedagogy, and content knowledge (TPACK) has three main sources of educator ICT integration knowledge, e.g.,. 1) Technology Knowledge (TK)knowledge of technological tools; 2) Pedagogy Knowledge (PK) knowledge of teaching methods; and 3) Content Knowledge (CK)-knowledge of subject matter (Koh and Chai, 2014). Media is generally used to support learning activities, namely presenting information and knowledge to individuals and groups. Picture media has a role in reducing the occurrence of misinterpretation in learning abstract information and knowledge such as physics [23].

Physics is important learning in various professions and fields regardless of gender with the hope of being able to be used to solve problems of modern society [24,25]. Physics subjects contain concepts that can be represented in the form of physical verbal, images, physical, and mathematical representations [26].

The level of conceptual understanding, especially physics learning, is realized through the way of interpreting learning problems. Interpretation of problems in learning physics can be done using simulations, graphs, and worksheets tutorial [27-30]. Mathematical representation serves as a guide in the arrangement of equations, but for students who are "lacking" in solving problems only practice the ability of mathematical representation [31]. Mathematical representation is usually conducted at the end because it serves to determine the result of a physical process [32].

That creativity is the ability possessed by students to solve problems from the knowledge they have to find possible answers to a problem using creativity measurement tools, namely verbal and figural creativity tests [33]. The differences in creativity based on fluency, flexibility, and novelty in solving mathematical problems and the problems being faced [34]. That creative assessment is provided for students, such

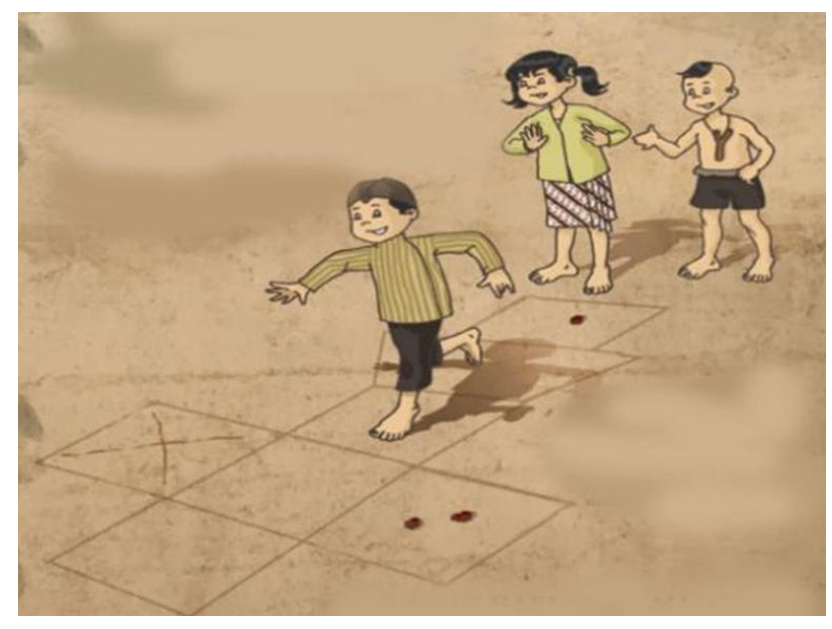

FIGURE 1. Hopscotch Game. as for study groups. Creative assessment skills are focused on originality, efficiency, flexibility, problem finding, and elaboration [35].

That every community has a good cultural value that is local wisdom [15]. Local wisdom as a product of local knowledge has provided a local context in the development of science [16]. Hopscotch of Engklek or also called sunda manda, ingkling, jlong jling, lempeng, or dampu is a traditional game commonly found in Sumatra, Java, Bali, Kalimantan, and Sulawesi. The traditional game of hopscotch, according to [19], contains the values of problem -solving, which consists of finding and understanding problems, compiling good problem- solving strategies, and exploring solutions. Hopscotch contains several physical concepts, including: Motion Dynamics (parabolic motion and displacement), Sound Waves, Rigid Body Equilibrium (center of gravity), and Impulse and Momentum.

Reference [36] states that television, radio, books, newspapers, magazines, and other media are tools and materials used to achieve the goals of education. Teachers can also use electronics for teaching purposes in class. The benefits obtained by teachers include: 1) broadening basic knowledge of teachers, 2) learning in the classroom to be flexible and dynamic, 3) can overcome limited teaching materials, 4) enrichment and contribution of teaching materials [37].

Comics are not only functioned as entertainment facilities but are also used in education. Comics are good educational tools to increase knowledge [38]. Comic books have features of humor, narrative, and visual representation and are potential media for science communication [39].

\section{Method}

This is a Research and Development (R and D) type of study. The development research of local wisdom based physics comic media: hopscotch game to improve mathematical representation and creative thinking ability of high school students uses the Borg and Gall model. The development of local wisdom based physics comic media: hopscotch game to improve mathematical representation and creative thinking ability of high school students starts from 1) preliminary research, 2) research design, 3) developing initial products, 4) limited test trials, 5) revision of limited trials, 6) initial field trials, 7) revision of initial field trials, 8) main field trials, 9) revision of main field trials, and 10) product dissemination.

The first stage of product development is analyzing the physical aspects of local wisdom: hopscotch game that can be seen in Table I. After the first stage is finished, then manually begin drawing using paper and pencil, and then scanned, editing process uses Adobe Photoshop CS5 software. The finishing stage uses Sigil software which can then be accessed on android using the application Himawari Reader, ReasilyEPUB Reader, other EPUB reader applications. The process of making comics can be seen in Figs. 2 to 4.

The research instruments used include product assessment sheets, student questionnaire responses, and tests of 


\begin{tabular}{|c|c|c|c|c|}
\hline Chapter & Variable & Aspect & Indicator & Treatment \\
\hline \multirow{5}{*}{ Impulses } & \multirow{3}{*}{$\begin{array}{l}\text { Creative } \\
\text { Thinking }\end{array}$} & Fluency & $\begin{array}{l}\text { Students explain the } \\
\text { impulsive force of the game }\end{array}$ & $\begin{array}{l}\text { Displayed when the lucky or gaco } \\
\text { comes in contact with the soil. }\end{array}$ \\
\hline & & Flexibility & $\begin{array}{l}\text { Students examine the picture or story } \\
\text { when there is a change in momentum. }\end{array}$ & $\begin{array}{l}\text { A picture is presented on the change } \\
\text { in momentum in the hopscotch game. }\end{array}$ \\
\hline & & Detail & Students describe Impulses in detail. & $\begin{array}{l}\text { A hopscotch player's foot is depicted } \\
\text { touching the gaco on the court. }\end{array}$ \\
\hline & \multirow{2}{*}{$\begin{array}{l}\text { Mathematical } \\
\text { Representation }\end{array}$} & $\begin{array}{l}\text { Mathematical } \\
\text { Equations }\end{array}$ & $\begin{array}{l}\text { Students can calculate the value of } \\
\text { impulses when the gacohits the ground. }\end{array}$ & $\begin{array}{l}\text { An image is displayed when } \\
\text { the gaco hits the ground. }\end{array}$ \\
\hline & & $\begin{array}{c}\text { Written } \\
\text { Text }\end{array}$ & $\begin{array}{l}\text { Students write the solution of the } \\
\text { impulse mathematical problem } \\
\text { in the movement of the gaco. }\end{array}$ & $\begin{array}{l}\text { Mathematical problems are } \\
\text { written of upon the gaco. }\end{array}$ \\
\hline \multirow{6}{*}{$\begin{array}{l}\text { Momentum } \\
\text { and } \\
\text { Collision }\end{array}$} & \multirow{4}{*}{$\begin{array}{l}\text { Creative } \\
\text { thinking }\end{array}$} & Fluency & $\begin{array}{l}\text { Students mention various } \\
\text { types of collisions }\end{array}$ & $\begin{array}{l}\text { Gaco of hopscotch game players } \\
\text { collide with each other is displayed }\end{array}$ \\
\hline & & Flexibility & $\begin{array}{l}\text { Students explain the } \\
\text { different kinds of collisions }\end{array}$ & $\begin{array}{l}\text { Gaco of hopscotch game players } \\
\text { collide inelastically with each other } \\
\text { is displayed. }\end{array}$ \\
\hline & & Novelty & $\begin{array}{l}\text { Students can design a variety } \\
\text { of collisions upon the gaco. }\end{array}$ & $\begin{array}{l}\text { Collisions between gaco with gaco } \\
\text { and gaco with the ground are displayed. }\end{array}$ \\
\hline & & Detail & $\begin{array}{l}\text { Students describe the momentum } \\
\text { and change in momentum }\end{array}$ & $\begin{array}{l}\text { Described the type of momentum } \\
\text { when the gaco clash with each other. }\end{array}$ \\
\hline & \multirow[t]{2}{*}{$\begin{array}{c}\text { Matematical } \\
\text { Representation }\end{array}$} & $\begin{array}{l}\text { Mathematical } \\
\text { Equations }\end{array}$ & $\begin{array}{l}\text { Students can calculate the type } \\
\text { of each collision on the gaco. }\end{array}$ & $\begin{array}{l}\text { The collisions between gaco with } \\
\text { each other or gaco with the ground } \\
\text { are displayed }\end{array}$ \\
\hline & & $\begin{array}{c}\text { Written } \\
\text { Text }\end{array}$ & $\begin{array}{l}\text { Students interpret the } \\
\text { momentum graph on the gaco. }\end{array}$ & $\begin{array}{l}\text { The momentum graph } \\
\text { is displayed. }\end{array}$ \\
\hline
\end{tabular}

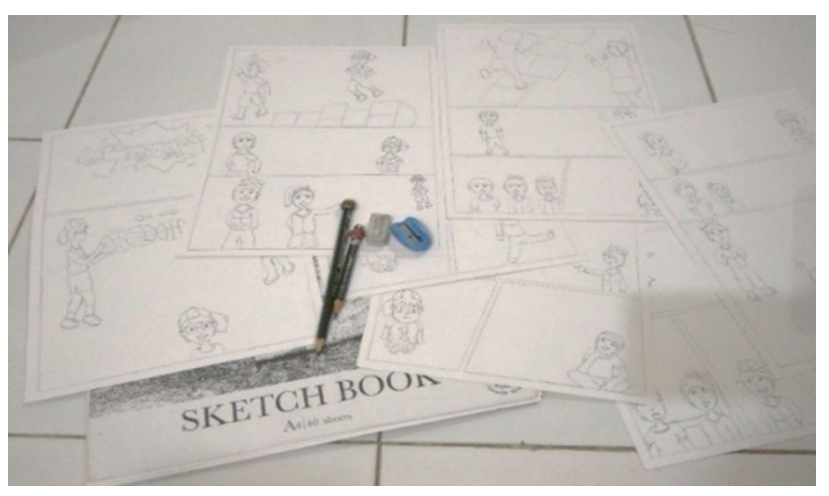

FIgURE 2. The Process of Making the Products with Paper and Pencils.

mathematical representation and creative thinking abilities. The research design is one group pretest-posttest design. The research subjects are high school students in 2018/2019 Academic Year, 30 students of Grade X Science for the initial field test and 60 students in Grade $X$ Science for the main field test. The data analysis technique used to determine the

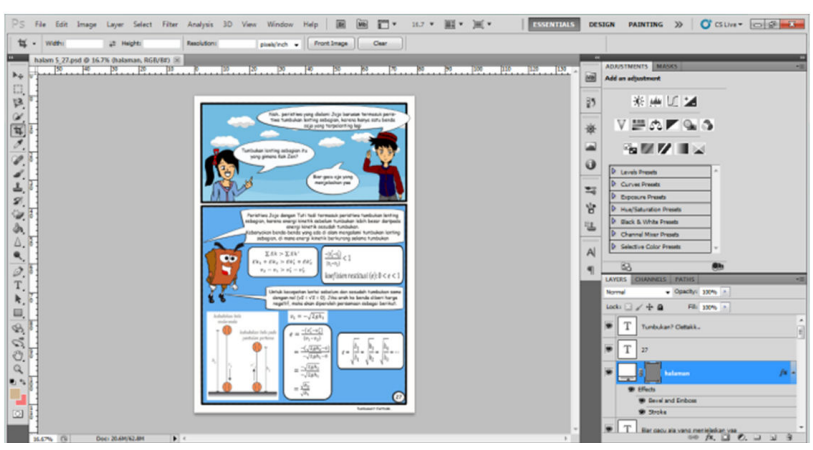

FIgure 3. The Product Manufacturing Process with Adobe Photoshop CS5 Software.

differences in the results of increased mathematical representation and creative thinking abilities is the MANOVA test with a significance level of 0.05 . The prerequisite test is carried out before analyzing the MANOVA test. The steps in the prerequisite test are described as follows [40]: 

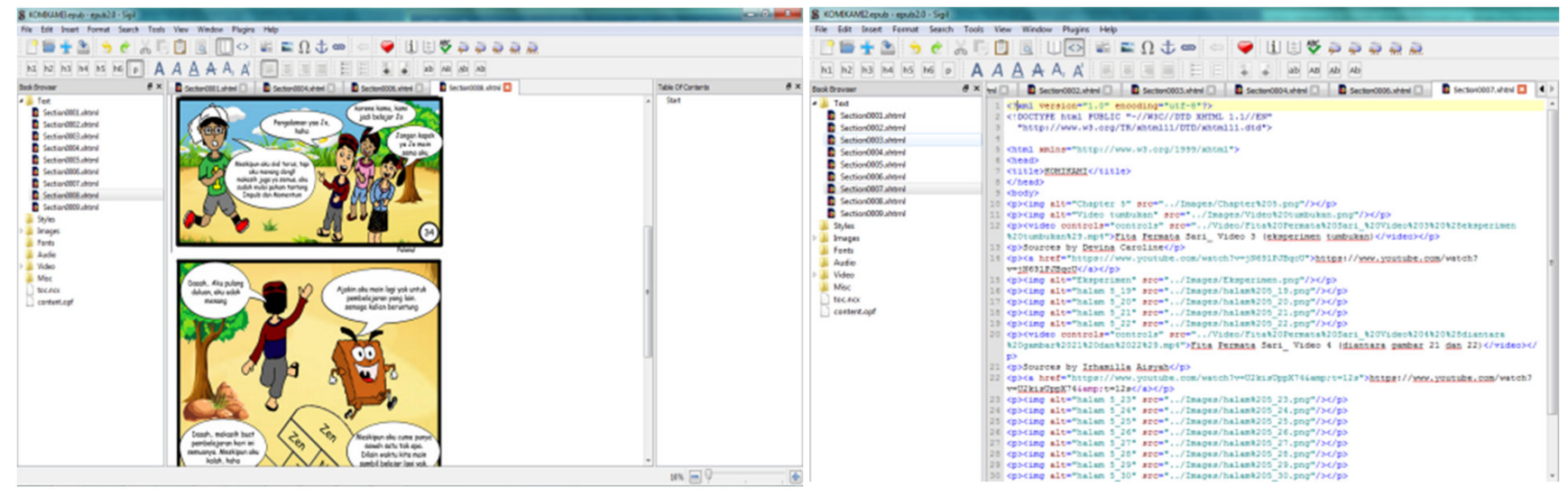

FIGURE 4. Sigil Display in the Product Making.

1) Contain two or more dependent variables in the form of continuous data.

2) Contain two or more categories of independent variables.

3) Observation of each class is different from the previous trial class.

4) The sample is sufficient with the number of students more than 25 for each class.

5) There are no univariate and multivariate outliers.

6) Multivariate normality test.

7) Linearity test.

8) Homogeneity test of variance-covariance matrix.

9) Correlation test (no multicollinearity).

If 9 prerequisite tests have been met, then the MANOVA test can be conducted using IBM SPSS Statistics 21 software.

\section{Result}

The results obtained are differences in learning outcomes using the media and without using media. These results can be obtained from the results of several analyses that have been carried out. Product trials produce test results in mathematical representation and creative thinking abilities of high school students. These results are described and can be seen in Table II and Table III.
Table II shows the gain values of the mathematical representation ability of experimental and control groups, which are 0.77 and 0.64 , respectively, and included in the high and medium categories, respectively. Based on Table II, the average pretest and posttest values of the mathematical representation ability of the experimental class have increased with a high category. Reference [41] explain that students can calculate and determine mathematical equations using mathematical representation abilities, although some students have difficulty in connecting concepts and mathematical representations. This is similar to the explanation of [42] that students need to understand the concept and visualize the problem to proceed to mathematical representation.

Table III shows the gain values of the creative thinking ability of experimental and control groups, which are 0.80 and 0.68 , respectively, and fall into the high and medium categories, respectively. Based on Table III, the average pretest and posttest values of the creative thinking ability of the experimental class have increased with a high category. This is relevant to the results of [43] that the learning process by using local wisdom media can increase the creativity of students. This is also related to the research of [12] that the learning process of physics can develop creative thinking and national character based on local wisdom so that it is able to balance between physical knowledge and national character based on the values of local wisdom in the society and the cultivation of scientific attitudes.

The statistical test used is multivariate analysis (MANOVA) to determine the effect of the local wisdom based physics comic media: android-assisted hopscotch game on the mathematical representation and creative think-

TABLE II. The Results of Mathematical Representation Ability.

\begin{tabular}{|c|c|c|c|c|c|c|}
\hline \multirow{3}{*}{ No } & \multirow{3}{*}{ Class } & \multirow{3}{*}{ Number of Learners } & \multicolumn{2}{|c|}{ Average Creative } & \multirow{3}{*}{ Average Gain Value } & \multirow{3}{*}{ Category } \\
\hline & & & \multicolumn{2}{|c|}{ Thinking Ability } & & \\
\hline & & & Pretest & Posttest & & \\
\hline 1 & Experiment & \multirow{2}{*}{30} & 29.50 & 83.50 & 0.77 & High \\
\hline 2 & Control & & 31.17 & 75.50 & 0.64 & Medium \\
\hline
\end{tabular}


TABLE III. The Results of Creative Thinking Ability.

\begin{tabular}{cccccccc}
\hline & & & \multicolumn{2}{c}{ Average Creative } & & \\
No & Class & Number of Learners & \multicolumn{2}{c}{ Thinking Ability } & Average Gain Value & Category \\
& & & Pretest & Posttest & & \\
& & \multirow{2}{*}{30} & 23.83 & 85.17 & 0.80 & High \\
2 & Experiment & & 18.00 & 74.00 & 0.68 & Medium \\
\hline
\end{tabular}

ing abilities of high school students. Nine steps of prerequisite test are carried out:

1) The dependent variables consist of mathematical representation and creative thinking in the form of continuous data.

2) The independent variables consist of two categories, namely comic media based on local wisdom of hopscotch game, which are tested in the experimental class and learning media, which are usually in school in the control class.

3) Observation of each class is different from the previous trial class.

4) Samples of control and experiment groups are 30 students each.

5) There are no univariate and multivariate outliers.

6) Multivariate Normality Test. The analysis of normality in the Shapiro-Wilk test obtains a sig. more than 0.05 . This means that the data of the experimental and control groups are normally distributed.

7) Linearity Test

8) Homogeneity test of the variance-covariance matrix. The homogeneity test using Box's Test obtains a sig. value of more than 0.05 , showing the values of the mathematical representation and creative thinking abilities relatively have the same variance.

9) Correlation test (No multicollinearity) Pearson Correlation result obtains a value of $r=0.338$ included in the weak category so that there is a correlation between the mathematical representation and creative thinking abilities in the experimental and control groups.

Table IV shows that there are significant differences between the independent variables (local wisdom based physics comic media of android-assisted hopscotch game) with all the dependent variables (mathematical representation and creative thinking abilities).

The results of MANOVA analysis show that the statistical value of the Hottelling's Trace test is 0.365 and the significance value indicates the value of $0.000<0.05$. The conclusion that can be drawn from this multivariate test is that there are differences in students' mathematical representation and creative thinking abilities between learning using local wisdom based physics comic media of android-assisted hopscotch game and learning using textbooks and the usual media provided by schools. The results of effective contributions given by each variable in each class are different meaning that there are differences in effectiveness for each class, i.e.

a. The effective contribution of the experimental and control classes is $94.3 \%$ and $92.3 \%$, respectively, for increasing mathematical representation and creative thinking skill abilities.

b. The effective contribution of the experimental and control classes is $91.4 \%$ and $87.7 \%$, respectively, for the improvement of mathematical representation ability.

c. The effective contribution of the experimental and control classes is $91.6 \%$ and $89.4 \%$, respectively, for the improvement of creative thinking ability.

TABLE IV. MANOVA Test Results.

\begin{tabular}{llccccccc}
\hline & Effect & Value & F & Hypothesis df & Error df & Sig. & Noncent. Parameter & Observed Power $^{c}$ \\
\hline \multirow{4}{*}{ Intercept } & Pillai's Trace & .991 & $3091.767^{b}$ & 2.000 & 57.000 & .000 & 6183.533 & 1.000 \\
& Wilks' Lambda & .009 & $3091.767^{b}$ & 2.000 & 57.000 & .000 & 6183.533 & 1.000 \\
& Hotelling's Trace & 108.483 & $3091.767^{b}$ & 2.000 & 57.000 & .000 & 6183.533 & 1.000 \\
& Roy's Largest Root & 108.483 & $3091.767^{b}$ & 2.000 & 57.000 & .000 & 6183.533 & 1.000 \\
\hline \multirow{3}{*}{ Class } & Pillai's Trace & .267 & $10.401^{b}$ & 2.000 & 57.000 & .000 & 20.803 & .984 \\
& Wilks' Lambda & .733 & $10.401^{b}$ & 2.000 & 57.000 & .000 & 20.803 & .984 \\
& Hotelling's Trace & .365 & $10.401^{b}$ & 2.000 & 57.000 & .000 & 20.803 & .984 \\
& Roy's Largest Root & .365 & $10.401^{b}$ & 2.000 & 57.000 & .000 & 20.803 & .984 \\
\hline
\end{tabular}



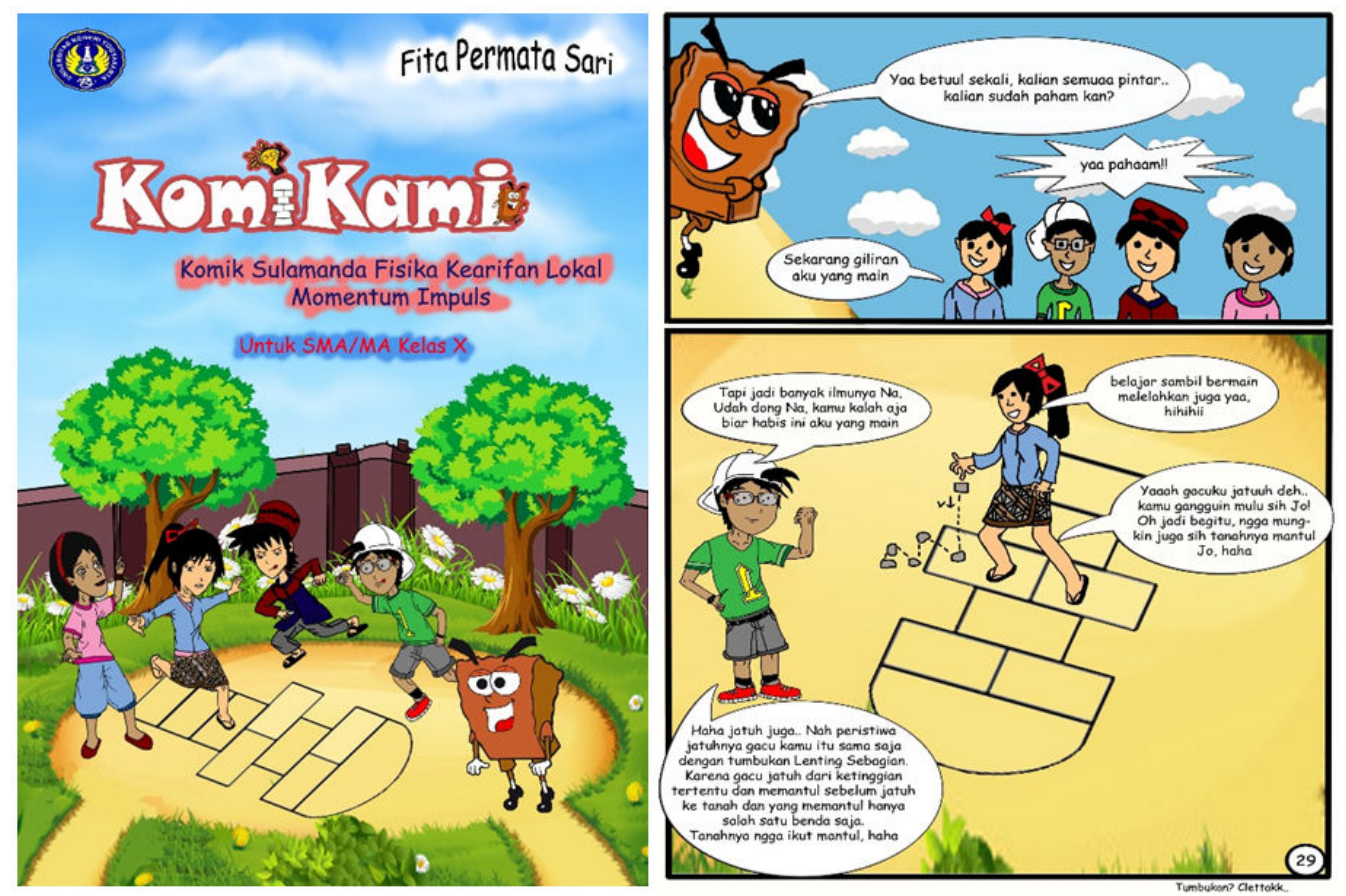

FIgURE 5. Physics Comic Based on Local Wisdom: Hopscotch Game Android-Assisted.

Some content examples of local wisdom based physics comic media: android-assisted hopscotch game produced in this development process can be seen in Fig. 5.

\section{Discussion and conclusion}

Local wisdom based physics comic media: android-assisted hopscotch game to improve mathematical representation and creative thinking abilities of high school students containing impulse and momentum material, learning videos, discussion sheets, experiment sheets, examples, and practice questions. The product can be operated using a smartphone with the Reasily-EPUB Reader application or other EPUB Reader application that can be downloaded at Playstore. The products can also be read using a computer using an internet browser. EPUB is a reader application used on smartphones to read files with the *.epub format. Students can easily read the learning material explained in detail and in full on the product because the product can be read anywhere and anytime using a smartphone. The products can also be read offline without having to connect to the internet. Students feel enthusiastic when the products made are tested in the classroom. However, there are still some students who are passive, because basically, they do not like to read. This product is good and suitable for use in the learning process in the classroom and outside the classroom. So that comics can be effective educational tools at various levels of education and are not only used as entertainment tools $[2,7,8]$. The development of Android-based physics comic media is appropriate to be used in physics learning in class and categorized as good for students [44].
The use of local wisdom based physics comic media: android-assisted hopscotch game can reduce the teacher's role as the main learning resource in the classroom. Comic media are considered easier to understand and more interesting compared to the books used [45]. Comic media in learning physics is better than the use of textbooks [46]. This media can be used anywhere and anytime without an internet connection. Students can read independently or be accompanied by a teacher. The results of the study by [2] shows that comics can be used to replace Student Worksheets. Reference [8] shows that comics can be used by elementary school students, high schools, and undergraduate students in the learning process. Science comics can be effective educational tools at various levels of education. Research from [11] shows that students provide positive responses in learning physics based on local wisdom in vocational high school. Comics is can be implemented in the physics learning process for students inside and outside the classroom [47]. So it can be stated that learning by using local wisdom based physics comic media: android-assisted hopscotch game can be effective and efficient. The impact of using media in learning activities is that students are more emphasized on the mathematical representation and creative thinking abilities. Another impact of using the product is that students have the ability to think at a high level because, by reading, they can also fantasize (imagine) according to the flow of the comics.

The results show that the local wisdom based physics comic media: android-assisted hopscotch game to improve mathematical representation and creative thinking abilities of high school students contains impulse and momentum material, learning videos, discussion sheets, sample experiment 
sheets, and practice exercises. The product can be operated using a smartphone with the EPUB-Reader application or a computer with an internet browser. Products are categorized as suitable for use in the physics learning process based on a feasibility assessment of 4.07 on a scale of 1 to 5 with a good category. There are differences in the results of the improvement of the mathematical representation and creative thinking abilities between the experimental and control classes with a significance level of $<0.05$. This shows that the local wisdom based physics comic media: android-assisted hopscotch game can improve the mathematical representation and creative thinking abilities of high school students.

\section{Acknowledgments}

This research was supported by Universitas Negeri Yogyakarta and Ristekdikti. We thank our colleagues from SMAN 1 Brebes, SMAN 2 Brebes, SMAN 1 Majenang, and MAN 2 Cilacap that greatly assisted the research.
1. J. J. Sheu and K. T. Chu, "Mining association rules between positive word-of-mouth on social network sites and consumer acceptance: A study for derivative product of animations, comics, and games," Telemat. Informatics 34 (2017) 2233. https://doi.org/10.1016/j.tele.2016.12. 010

2. P. D. Widyastuti, M. Mardiyana, and D. R. S. Saputro, "An Instructional Media using Comics on the Systems of Linear Equation," J. Phys. Conf. Ser. 895 (2017) 012039. https: //doi.org/10.1088/1742-6596/895/1/012039

3. S.-F. Lin, H. Lin, L. Lee, and L. D. Yore, "Are Science Comics a Good Medium for Science Communication? The Case for Public Learning of Nanotechnology," Int. J. Sci. Educ. Part B 5 (2015) 1-19. https://doi.org/10.1080/21548455. 2014.941040

4. I. Irwandani and S. Juariyah, "Pengembangan Media Pembelajaran Berupa Komik Fisika Berbantuan Sosial Media Instagram sebagai Alternatif Pembelajaran," J. Ilm. Pendidik. Fis. Al-Biruni, 5 (2016) 33. https://doi.org/10.24042/ ijsme.v3i1.5059

5. J. L. P. Ribeiro, "A plane mirror experiment inspired by a comic strip," Phys. Educ. 51 (2016). https://doi.org/ $10.1088 / 0031-9120 / 51 / 1 / 015011$

6. M. Bitz and O. Emejulu, "Creating Comic Books in Nigeria: International Reflections on Literacy, Creativity, and Student Engagement," J. Adolesc. Adult Lit., 59 (2016) 431-441. https://doi.org/10.1002/jaal.451

7. D. di Fuccia, T. Witteck, S. Markic, and I. Eilks, "Trends in Practical Work in German Science Education," Eurasia $J$. Math. Sci. Technol. Educ. 8 (2012) 59-72. https://doi. org/10.12973/eurasia.2012.817a

8. J. Kim, M. S. Chung, H. G. Jang, and B. S. Chung, "The use of educational comics in learning anatomy among multiple student groups," Anat. Sci. Educ. 10 (2017) 1-8. https: //doi.org/10.1002/ase.1619

9. S. F. Lin and H. S. Lin, "Learning nanotechnology with texts and comics: the impacts on students of different achievement levels," Int. J. Sci. Educ. 38 (2016) . 1373-1391 https: //doi.org/10.1080/09500693.2016.1191089

10. M. Kim and T. Aktan, "How to enlarge the scope of the curriculum integration of mathematics and science (CIMAS): A delphi study," Eurasia J. Math. Sci. Technol. Educ. 10 (2014) 455469. https://doi.org/10.12973/eurasia.2014. $1115 \mathrm{a}$
11. M. N. Sholakhudin, Sutarto, and Subiki, "Paket Sumber Belajar (PSB) dengan Analisis Foto Kejadian Fisika (AFKF) Berbasis kearifan Lokal pada Pembelajaran Fisika di SMK (Kajian Pengembangan pada Pokok Bahasan Fluida untuk SMK Jurusan Perikanan dan Kelautan)," J. Pembelajaran Fis. 5 (2016) 253-260.

12. I. W. Suastra and L. P. B. Yasmini, "Model Pembelajaran Fisika Untuk Mengembangkan Kreativitas Berpikir dan Karakter Bangsa Berbasis Kearifan Lokal Bali," J. Pendidik. Indones., 2 (2013) 221-235. http://dx.doi.org/10. $23887 / j p i-u n d i k s h a \cdot v 2 i 2.2166$

13. J. L. Docktor and J. P. Mestre, "Synthesis of disciplinebased education research in physics," Phys. Rev. Spec. Top. Phys. Educ. Res., 10 (2014) 1-58. https : //doi.org/10. 1103/PhysRevSTPER.10.020119

14. T. T. Y. Wong, "The unique and shared contributions of arithmetic operation understanding and numerical magnitude representation to children's mathematics achievement," J. Exp. Child Psychol., 164 (2017) 68-86.https: // doi.org/10. $1016 / j \cdot j e c p .2017 .07 .007$

15. U. Fajarini, "Peranan Kearifan Lokal Dalam Pendidikan Karakter," Sosio Didakt. Soc. Sci. Educ. J., 1 (2014) 123-130. 10. $15408 / \mathrm{sd} . v 1 i 2.1225$

16. A. Anwari, M. S. Nahdi, and E. Sulistyowati, "Biological science learning model based on Turgo's local wisdom on managing biodiversity," AIP Conf. Proc., 1708 (2016) 1-6. https: //doi.org/10.1063/1.4941146

17. I. Meliono, "Understanding the Nusantara Thought and Local Wisdom as an Aspect of the Indonesian Education," TAWARIKH Int. J. Hist. Stud., 2 (2011) 221-234. https: //doi.org/10.2121/tawarikh.v2i2.392

18. I. P. W. Y. Pramadi, I. W. Suastra, and I. M. Candiasa, "Pengaruh Penggunaan Komik Berorientasi Kearifan Lokal Bali terhadap Motivasi Belajar dan Pemahaman Konsep Fisika," $e$ Journal Progr. Pascasarj. Univ. Pendidik. Ganesha, (2013) 3.

19. Iswinarti, "Nilai-nilai Problem Solving Permainan Tradisional Engklek," Semin. Nas. dan Gelar Prod., (2017) 1-9.

20. Y. Hadzigeorgiou, P. Fokialis, and M. Kabouropoulou, "Thinking about Creativity in Science Education," Creat. Educ. 03 (2012) 603-611. DOI : 10.4236/ce.2012.35089 
21. Suyono and Hariyanto, Belajar dan pembelajaran. Bandung, Indonesia: PT Remaja Rosdakarya Offset, (2014).

22. H. Georgiou and M. D. Sharma, "Does using active learning in thermodynamics lectures improve students' conceptual understanding and learning experiences?," Eur. J. Phys. 36 (2015) 113. https://doi.org/10.1088/0143-0807/36/1/ 015020

23. B. A. Pribadi, Media dan teknologi dalam pembelajaran. Jakarta, Indonesia: Kencana, (2017) .

24. M. Baran, “An Analysis on High School Students' Perceptions of Physics Courses in Terms of Gender (A Sample from Turkey)," J. Educ. Train. Stud. 4 (2016) 150-160. https: //doi.org/10.11114/jets.v4i3.1243

25. S. Bates, R. Donnelly, C. Macphee, D. Sands, M. Birch, and N. R. Walet, "Gender differences in conceptual understanding of Newtonian mechanics: A UK cross-institution comparison," Eur. J. Phys. 34 (2013) 421-434. https://doi.org/10. 1088/0143-0807/34/2/421

26. G. Rizky, D. Tomo, and Haratua, "Kemampuan multirepresentasi siswa sma dalam menyelesaikan soal-soal hukum newton," J. Pendidik. dan Pembelajaran, 3 (2014) 1-10.

27. P. Barniol and G. Zavala, "A tutorial worksheet to help students develop the ability to interpret the dot product as a projection," Eurasia J. Math. Sci. Technol. Educ., 12 (2016) 2387-2398. https://doi.org/10.12973/ eurasia.2016.1271a

28. A. Ferreira, A. S. Seyffert, and M. Lemmer, "Developing a graphical tool for students to understand air resistance and free fall: When heavier objects do fall faster," Phys. Educ., 52 (2017) 1-9. https://doi.org/10.1088/1361-6552/ aa65da

29. T. I. Smith, J. R. Thompson, and D. B. Mountcastle, "Student understanding of Taylor series expansions in statistical mechanics," Phys. Rev. Spec. Top. - Phys. Educ. Res. 9 (2013) 116. https://doi.org/10.1103/PhysRevSTPER.9. 020110

30. Z. Uddin, M. Ahsanuddin, and D. A. Khan, "Teaching physics using Microsoft Excel," Phys. Educ., 52 (2017) 1-6. https : //doi.org/10.1088/1361-6552/aa7919

31. D. P. Cartrette and G. M. Bodner, "Non-mathematical problem solving in organic chemistry," J. Res. Sci. Teach. 47 (2010) 643660. https://doi.org/10.1002/tea.20306

32. G. Leigh, "Developing Multi-representational Problem Solving Skills in Large, Mixed-ability Physics Classes," (2004).

33. N. Fitriani, G. Gunawan, and S. Sutrio, "Berpikir Kreatif dalam Fisika dengan Pembelajaran Conceptual Understanding Procedures (CUPs) Berbantuan LKPD," J. Pendidik. Fis. dan Teknol. 3 (2017) 24-33. http://dx.doi.org/10. 29303/jpft.v3i1.319

34. D. Sambada, "Peranan Kreativitas Siswa Terhadap Kemampuan Memecahkan Masalah Fisika dalam Pembelajaran Kontekstual," J. Penelit. Fis. Dan Apl. 2 (2012) 37-47. http: //dx.doi.org/10.26740/jpfa.v2n2.p37-47
35. J. Raiyn and O. Tilchin, "Assessment of adaptive PBL's impact on HOT development of computer science students," J. Educ. Pract. 6 (2015) 51-58.

36. W. Sanjaya, Strategi pembelajaran. Jakarta, Indonesia: Kencana Prenada Media Group, (2006).

37. D. Darmawan, Mobile learning sebuah aplikasi teknologi pembelajaran. Jakarta, Indonesia: Rajawali Press, (2016) .

38. E. Özdemir, "Humor in Elementary Science: Development and Evaluation of Comic Strips about Sound" Int. Electron. J. Elem. Educ. 9 (2017) 837-850.

39. A. Mendelson et al., "Comics as an educational tool for children with juvenile idiopathic arthritis," Pediatr. Rheumatol., 15 (2017) 1-6. https://doi.org/10. 1186/s12969-017-0198-5

40. J. P. Stevens, Applied multivariate statistics for the social sciences. London, Inggris: Lawrence erlbaum associates, (2002).

41. V. Albe, P. Venturini, and J. Lascours, "Electromagnetic Concepts in Mathematical Representation of Physics," J. Sci. Educ. Technol. 10 (2001) 197-198. https://doi.org/ 10.1023/A:1009429400105

42. H. Tms and J. Sirait, "Representations Based Physics Instruction to Enhance Students' Problem Solving," Am. J. Educ. Res. 4 (2016) 1-4. DOI : 10.12691/education-4-1-1

43. A. Pamungkas, B. Subali, and S. Linuwih, "Implementasi Model Pembelajaran IPA Berbasis Kearifan Lokal untuk Meningkatkan Kreativitas dan Hasil Belajar Siswa," J. Inov. Pendidik. IPA, 3 (2017) 118-127.

44. F. P. Sari, L. Ratnaningtyas, I. Wilujeng, Jumadi, and H. Kuswanto, "Development of Android Comics media on Thermodynamic Experiment to Map the Science Process Skill for Senior High School," J. Phys. Conf. Ser. (2019) 0-9. https: //doi.org/10.1088/1742-6596/1233/1/012052

45. L. Aslamiyah, M. Masturi, and S. E. Nugroho, "Pengembangan Media Pembelajaran Komik Fisika Berbasis IntegrasiInterkoneksi Nilai-Nilai Alquran," Unnes Phys. Educ. J. 6 (2017) 45-52 . https://doi.org/10.15294/upej. v6i3.19271

46. H. Avrilliyanti, S. Budiawanti, and J. Jamzuri, "Penerapan Media Komik untuk Pembelajaran Fisika Model Kooperatif dengan Metode Diskusi pada Siswa SMP Negeri 5 Surakarta Kelas VII Tahun Ajaran 2011/(2012) Materi Gerak," J. Pendidik. Fis. 1 (2013) 156-163.

47. F. P. Sari, S. Nikmah, H. Kuswanto, and R. Wardani, "Developing Physics Comic Media a Local Wisdom: Sulamanda (Engklek) Traditional Game Chapter of Impulse and Momentum Developing Physics Comic Media a Local Wisdom: Sulamanda (Engklek) Traditional Game Chapter of Impulse and Momentum," J. Phys. Conf. Ser. 1397 (2013) 2019. https : //doi.org/10.1088/1742-6596/1397/1/012013 